Studia UBB 㚼igitalia, Volume 62 (LXII) 2017, December, Issue 2, 7-24

Published Online: 2017-12-30

DOI:10.24193/subbdigitalia.2017.2.01

\title{
The programmer and the scholar: A conversation
}

\author{
Willard McCarty \\ Professor Emeritus, \\ King's College London
}

\begin{abstract}
The prospects of a new centre for digital humanities brings to mind those once prominent centres that have disappeared, hence the question of what they did or did not do that would have made the difference. Here I suggest that they failed for lack of an intellectual agenda. Drawing from the early history of digital humanities, an ethnographic vignette of my own research, close attention to the machinery of computing and work in the history of the physical sciences, I suggest a beginning to such an agenda.
\end{abstract}

Keywords: Digital humanities; modelling; agenda; collaboration; interdisciplinary research; absolute consistency and complete explicitness; markup

The Transylvanian monarch and scholar Matthias Corvinus, born in Cluj in 1443 (Figure 1), was regarded by the Florentine Platonist Marsilio Ficino as a true philosopher-king, potentia simul et sapientia, ${ }^{1}$ a man of both power and wisdom. Inspired by Ficino's lofty prose, I take that great king as allegorical hero in the quite different story of the programmer's potentia and the scholar's sapientia in our modest domain of digital humanities. This story is perhaps most often of collaboration between individuals, even within teams. But such collaboration depends fundamentally on those individuals coming to understand, indeed to think like each other, and so to converge on

${ }^{1}$ Epistolae IV.121, to Francisco Bandini (Nürnberg: Anton Koberger, 1497). For readers of English Ficino's letters are most conveniently found in the 10-volume edition published by Shepheard-Walwyn. On Matthias Corvinus and the Italian Renaissance see Farbaky and Waldman. 
the scholar-programmer whose internal, cognitive enactment of action and reason together is my subject here. I will ground what I have to say about that enactment in an ethnographic vignette of a research project from which I learned most of what I know about computing in the humanities. ${ }^{2}$ My aim is to bring what I have learned to bear on the historical disciplinary situation in which the fledgling Centrul Digital Humanities Transilvania finds itself. I begin there, then move on to scholar and programmer.

\section{Centres and the incunabular period}

A new centre for digital humanities is both exciting and gratifying to someone who has been around long enough to witness the struggle for recognition of the field as an intellectual endeavour. But it is not the case that practitioners can now relax, and not only because of the occasional rant against the field, denial that it is one or its mindless popularity. Digital humanities is only about 70 years old and has nothing like an overall sense of direction. It is still feeling around in the dark, its popularity in some places shedding more heat than light. This is not to say that good work isn't being done. Nor is it to say that past efforts have no value for the present - quite the opposite. One big problem is that we have paid too little attention, or none, to the history of those feelings-around in the dark, little or no attention to a history that would help illumine where we might be going. We have not asked, for example, why so many centres of computing in the humanities have disappeared - a topic that has been proposed several times for the annual conference but never taken up as far as I know. Lack of a good answer lessens our ability to build centres that will last.

A new one, such as the Transylvania Digital Humanities Centre, has the advantage of being in a position to observe the successes and failures of those who have gone before, learn from them and then plot its own, different, locally shaped, perhaps better trajectory. But in looking to these predecessors the aim has to be to learn from them, not just imitate. Disciplines, after all, even those which have been around for millennia, are not in essence templates for research nor clubs with rules and codes of behaviour. A discipline isn't a thing. It is what students of a subject do. It is a starting-point, a living social entity to be shaped and directed.

Among the principal reasons for the failure of many past centres has been, I think, the lack of a distinct intellectual agenda. ${ }^{3}$ No field can be a discipline unless it has something like a common understanding of what is to be done. This understanding

\footnotetext{
${ }^{2}$ I am indebted to anthropologist Dr Amiria Salmond, who in a long and intense e-mail correspondence suggested I write this vignette as a way of clarifying my ideas.

${ }^{3}$ On agendas, with a focus on computer science, see Mahoney, 165.
} 
is usually tacit, difficult to see from the outside but often demonstrated by the presidential addresses of national and international scholarly associations, acceptance speeches for the awards they bestow, plenary lectures at major conferences and the like. Michael Sperberg-McQueen once said to me that if you want to know what computer science is all about you read the Turing Award Lectures. ${ }^{4}$ On that score as well, we are a rather weak lot, having paid very little attention to the fundamental role these occasions and venues play in encouraging the development of the critical thought at the basis of disciplinary life. Alan Liu has complained that we don't have much of it, and he's right (Liu). His is the handwriting on the wall. (Figure 2) Ultimately, there comes a reckoning at which a cogent argument must be made for spending collective resources on the newcomer. Within academia how else is the newcomer to prepare for it except by forging a strong connection with the fundamental purpose of the university, with its agenda, and thus fitting into the society of colleagues?

The centres which have flowered and then withered or been absorbed into service-units, e.g. at Bergen, Oxford and Toronto (where I was for a dozen years) were launched at a time when contact with computing was fatal to a normal academic career for any doctoral student in the humanities and damaging to the reputation of a professor associated with it. Initiatives in digital humanities had to cross-dress, sometimes in the livery of a servant, sometimes in the slick outfit of a salesman, and their budgets had to be protected by deference and salesmanship against collegial piracy. Any talk of an intellectual agenda that did occur tended to be about the research objectives of curious professors who came to such centres for help. As one of those employed to help, I was exposed to research across the disciplines. Although this employment constituted a black mark academically, it gave me invaluable training by affording me the opportunity to see potential for common ground within which an intellectual agenda for computing in the humanities might grow. I took what I thought to be the central problem, formulated a research project of my own and, stealing time from the day-job, pursued it. I will return to this project in a moment.

Disciplinary amnesia has obscured what was going on with computers in those early years, what I call the incunabular period from the 1960s until, in the 1990s, the World Wide Web brought that period to an end. Its history is beyond my scope here; in fact, no proper history of it has been written. But I want to pull from what I know about it a central failure and two sources of insight.

I have pointed to the historical problem of an agenda for the field, but I did not say anything about how to form one. How do we know what needs doing in order to supply a lack others will recognise as a lack, or to fix something they will agree is broken?

\footnotetext{
${ }^{4}$ http://amturing.acm.org/lectures.cfm. Accessed 29 November 2017.
} 
Incunabular digital humanities failed to gain a foothold in the academy primarily, I think, because practitioners did not develop a theoretical understanding of the field, which for a fundamentally interdisciplinary, methodological enterprise is to say, how the field fits into the intellectual ecology of the arts and letters, what it has to offer of intellectual value that others see they need, and what they have to offer that it needs. Having developed no such understanding, practitioners were unable to interest mainstream colleagues, to relate to and learn from them, to persuade them a new field was worth supporting.

Throughout the incunabular period, insiders on both sides of the Atlantic repeatedly sifted for 'evidence of value' to the academy but found little. Matters came to a head at the end of the 1980s and beginning of the 90 s, for example in overviews by literary critic Rosanne Potter and by historian of French literature Mark Olsen, who declared the field's major preoccupation, with text-analysis, to be a waste of time. ${ }^{5}$ There was much fuss among colleagues; Olsen had constructive suggestions; but no overall theoretical understanding emerged. About that time, in well-informed assessments of the field, the philosopher, historian and classicist Sir Anthony Kenny (who in 1982 had published the standard introduction to statistics for students of the humanities and who had applied computational stylistics to Aristotle) found the harvest of three decades' work disappointing and use of computing in research possibly damaging. ${ }^{6}$ To my knowledge, no riposte was offered. Kenny pointed to classicist Robert Connor's question of why, just as the computer was coming into the humanities, scholars were abandoning the kinds of enquiry with which it would have helped. Few if any articulated the connection between the connotations of the technoscientific machine and the sinister machinations of the Cold War. But then in 1991, almost simultaneously, the Web was released to the public and the Soviet Union collapsed. Less than a decade later the Web became visible to the humanities, and Franco Moretti started talking about 'distant reading' (Moretti). But note well: the problems which had retarded the development of our field were not made obsolete or irrelevant by the Web, rather they were temporarily shoved aside by the compelling imperative to stock the virtual shelves.

The incunabular period is worth more than delineation of missed opportunities and certain pregnant questions about the relation between technoscience, the humanities and the lives of ordinary citizens. It is also where we find enthusiasm for the possibilities of computing and great insight. The two best sources of insight from the period are to

\footnotetext{
${ }^{5}$ See Potter "Literary Criticism and Literary Computing: The Difficulties of a Synthesis"; "Literary Computing and Literary Criticism: Theoretical and Practical Essays on Theme and Rhetoric" xv-xviii and "Statistical Analysis of Literature" 402-7; Olsen "What can and cannot be done with electronic text" and "Signs, Symbols, and Discourses" (a revised version of the first cited work) which headed a double-issue of CHum dedicated to responses.

${ }^{6}$ See esp. Kenny, the clearest statement of his view.
} 
my mind philologist Fr Roberto Busa and literary critic Louis Milic, both of whom argued cogently against the tendency of scholars to apply the machine to what it could most easily do, in other words to treat it as a labour-saving device of automation. Busa's primary emphasis was enabling more scholarly work with more penetrating questions. Envisioning the possibilities in 1976, he asked "Why can the computer do so little?" 7 As others were churning out concordances for print and celebrating the time and labour saved, he argued that "operating on texts only in terms of individual words... [is] a rather poor performance." In 1966 Milic zeroed in on the unexamined nature of the machine. He pointed to understanding of it as the primary goal, somewhat in the manner of an anthropologist's project to understand a profoundly different culture. He wrote that,

The true nature of the machine is unknown to us, but it is neither a human brain nor a mechanical clerk. The computer has a logic of its own, one which the scholar must master if he is to benefit from his relations with it. Its intelligence and ours must be made complementary, not antagonistic or subservient to each other.... The computer can be made an extension of man only if it opens avenues we have not suspected the existence of. Thinking in a new way is not an easy accomplishment. It means re-orientation of all the coordinates of our existence.... What the computer will enable us to do in our humanistic tasks has hardly been imagined yet. (Milic $4 \mathrm{f}$ )

He entitled his article "The next step". As I like to say, it's a step we have not yet taken.

\section{Scholar - programmer (Figure 3)}

I have entitled this talk "The scholar and the programmer: A conversation". As I said at the beginning, I don't limit myself to two kinds of people, separated in space, talking and listening to each other. Rather I mean two states of being in an evolving cognitive resonance. These two states can exist within the same person or be realised in an external collaboration between quite different people. Nor do I see these as alternatives, rather as simultaneous. The otherness of an other person may be close to essential for developing good research in our field. But without the internal conversation, how can the external one get anywhere at all?

\footnotetext{
${ }^{7}$ Busa "Why can a computer do so little?"; see also Busa "The Annals of Humanities Computing".
} 
To explore the relationship between scholar and programmer I want to use the research I did in that forgotten, incunabular period to sketch what a serious problem in the humanities looks within either the internal or external relationship. I offer my own ethnographic vignette not because I think it more insightful than another's but because I don't know of any other to use. More of them would be helpful.

\section{Modelling}

I came on the scene as a doctoral student of English literature in the late 1970s and then as a newly minted $\mathrm{PhD}$ in the mid 1980s looking for questions to ask. (I had started with computing, in the form of those legendary mainframes, in the mid 1960s, but that's another story.) I became fascinated with the extravagant claims being made by enthusiastic colleagues and so decided to see for myself. About that time Brian Cantwell Smith made two fundamental observations implicit in the design of the stored-program computer: first, that the machine can do nothing useful without a model of whatever it is to compute; second, that no model can be correct in an unqualified sense: it is necessarily an interpretative simplification of the modelled object or situation (Smith). Even then, in the 1980s, given the slow rhythm of computer-use, it was difficult to impossible for the ordinary user to see that with technical progress true human-computer interaction would become possible, and with it crucial changes would occur: (1) 'model' would come to be understood not as a static design but a momentary state in the process of modelling; (2) the inability of any model to be correct would become the driving force of that process; and (3) as a result, the modeller as participant would, as it were, move inside the modelling process as it moves inside him or her. I will come back to that virtual move later.

By the time I wrote Humanities Computing in 2005 this change had happened, hence my emphasis on modelling in that book (McCarty Chapter 1). But in the early 1980 s I had to learn the hard way. So my focus was on building and perfecting a model of something step by step. Doing that allowed me to bring the logic of the digital into sharp focus.

\section{The Onomasticon}

The question I took up was the standard literary one of poetic unity. I asked this question about a poem that had captured me while I was working on the doctorate: the Metamorphoses by the Roman poet Ovid - who, by the way, spent his last years not far from Cluj, in exile among the Thracian Getae, in what is now the Romanian city of Constanța on the western shores of the Black Sea. 
Ovid's Metamorphoses is a large, elusively structured compilation of teasingly interrelated mytho-historical stories in 15 books, amounting to 12,000 lines of classical Latin hexameter. (Figure 4 is a suggestive illustration from George Sandys' $17^{\text {th }}$-century translation and commentary, Ovid's Metamophosis Englished, Mythologiz'd And Represented in Figures.) Since its composition ca. 100CE the poem has had enormous historical, literary and artistic influence, making it fundamental within the European cultural tradition. Nevertheless in modern times it has been poorly understood, often thought to be little more than a convenient miscellany, like Apollodorus' Library. When I became interested in it, literary scholarship on the Met was largely preoccupied with realising "the immortal dream of a universal key", as one exceptional critic noted of a most ambitious attempt. ${ }^{8}$ It and other such attempts did not succeed. I wanted to do better.

My approach as a digitally educated literary scholar was to look for a textual phenomenon distributed throughout the poem whose occurrences could be treated as computationally tractable data but that also was strongly linked to the structural basis of the poem, its stories. The names of persons, a few hundred in number, seemed to fit the bill perfectly. Thus I called the intended tool an Onomasticon, a 'book of names'. ${ }^{9}$ From the beginning my goal was to provide others with a tool that would allow exploration of structural patterns at the level of narrative without committing the user to any particular idea of how stories might link to each other. The reception-history of the Met suggests that readers quite often would begin with a favourite story. What, then, would the whole poem look like from this or that initial perspective? How would the poem as a whole inform the chosen story?

Closer inspection forced me to realise that fixing on proper names alone would miss too much: Ovid's Latin provides an abundance of means for indicating a person without using his or her proper name. Hence I had to expand the category 'name' to all devices of language referring to a person, including pronouns, verbs, personal attributes and effects. In the end there turned out to be ca. 60,000 of them, i.e. an average of 5 per line of poetry, confirming the potential of the Onomasticon to embrace the entirety of the Met and committing me to far more work than I had anticipated.

Manual tagging followed so that I could say, e.g., 'here is a mention of person Tereus, named by lemma arma auxiliaria in category attribute'. (Examples are to be found in the online version of the Onomasticon. ${ }^{10}$ ) I began before the Text Encoding

\footnotetext{
${ }^{8}$ Due 135 , on Otis.

${ }^{9}$ For the ideas and problems involved in constructing the Onomasticon, see McCarty "Encoding persons and places 1" and "Encoding persons and places 2".

${ }^{10} \mathrm{http}: / /$ www.mccarty.org.uk/analyticalonomasticon/. Accessed 29 November 2017.
} 
Initiative was a force to be reckoned with. But I would have decided to invent my own coding system in any case - to invent it gradually in response to the requirements of the poem - so as to allow the theory of text this system implemented to be as specific to the poem as possible. My objective, as I suggested earlier, was to avoid all interpretation, a deliberately naïve stance that I took with two objectives in mind: first, to keep the work as clean of interpretative prejudice as possible; second, in order to see up close what computing a cultural object would actually entail - what it would cost. (Here is a motto for digital humanists to live by: there is always a tradeoff.) To say that resistance to interpretation proved futile is the grossest of understatements. A very large majority of entities to be tagged made interpretation both unavoidable and difficult: not only is ambiguity essential to human language, especially poetry, but the Metamorphoses itself also plays on ambiguities to subvert every ontology it tempts the reader to construct. The poet puts forth possibilities of closure only to dodge them. A 'universal key' to a defining structure, a different key for each reader or for each interpretative stance - all are impossible in the face of a continual, unresolvable, metamorphic, proliferation of structurings. The poem enacts the poet's subject, metamorphosis, in such a way that the Metamorphoses cannot be wrapped up in a neat taxonomy. As the reading progresses, and scheme after scheme collapses, the frustrating attempt reveals an illimitable, multidimensional process. This process is, I would argue, the poem's greatest gift and the guarantee of the poet's final declaration, ... perque omnia saecula fama, / siquid habent veri vatum praesagia, vivam, "and if the prophecies of bards are true, through all the ages in fame I will live" (Met 15.878-9).

Thanks to a Canadian government grant I was able to hire a research assistant, Burton Wright, whose role was to personify the programmer, I the scholar, but roles became quite blurred. In both cases, otherness of another mind kept us from stultifying fascination with our own coding. We formed a close working relationship, but in time, he left for pastures new, and other research assistants followed. Eventually I abandoned the project, finally realising that no adequate model of the Metamorphoses was possible nor was any existing or conceivable tool capable of modelling the poem without embedding deeply, extensively and for all practical purposes ineradicably the prejudicial interpretations of the maker - therefore defeating the purpose of the Onomasticon.

\section{An axiom of digitisation}

So where did this leave me? Let me summarise. The Onomasticon demonstrated several things, chiefly that metatextual encoding was a powerful instrument for stimulating literary interpretation but wholly inadequate for communicating it; that the unresolvable 
polarisation of scholar and programmer was a fundamental theoretical result essential to understanding the creative potential and epistemology of digital research; and that its dynamics is a central problem of the field. I will come back to this problem below.

My experience also led me to formulate what I have come to call the axiom of digitization: that whatever is to be computed must be rendered in a completely explicit and absolutely consistent form. In consequence, a stark difference between reading and encoding (parallel to the difference between scholar and programmer) emerges. At the time I was unaware that historian of science David Gooding was on course to reach the same conclusion from his work on Michael Faraday's meticulously kept laboratory notebooks. Here is what Gooding wrote in 2003:

To digitalize is to represent features of the world, including relationships between them, in a manner that establishes and fixes unambiguous meaning.... It is a method designed to achieve two things: to preserve the invariance of tokens in a symbol manipulation system and to make the value of the tokens unambiguous. (279 and 283 n. 33)

I had concluded from my own work that the principal benefit of digital computing is a kind of via negativa, a 'negative path' that illumines the unknown by showing what algorithms cannot do - much in the spirit of Turing's paper on the Entscheidungsproblem (Turing "On computable numbers"). But then computers became faster, more capacious and cheaper, hence personal machines, and so computing ever more of a process, ever less of an event. In consequence modelling became a focus of attention, and so the polarisation of scholar and programmer ever more the precondition of a resonance between them. Gooding depicted the situation as shown in Figure 5.

\section{Actual computation}

So much for the reductive phase with its not inconsiderable gift. But Gooding's diagram illumines two others: the middle phase of actual machine computation, and the final phase at which the enquirer retranslates computational results back into the terms of his or her research. Probing these will take us to the end of this paper.

We may think of operations in this middle phase as mechanical as opposed to human, but since the machine is a human artefact, it is more productive to ask after the model of thought-processing the machine instantiates - its built-in 'theory of mind', if you will. Go back to Turing's 1936 and von Neumann's 1945 papers, and what do we find? Consider the brief snippets shown in Figure 6: first the metaphor of the man doing 
his sums, with which Turing begins, second von Neumann's use of neurophysiological vocabulary in his sketch of an architecture for the digital machine - the machine's 'organs', with which it carries out the human mathematical forms of addition, multiplication, subtraction, division, and so on. Between these two documents stands Warren McCulloch's and Walter Pitts' proposal of a model of the brain as a Turing Machine, which von Neumann read. ${ }^{11}$

Many have said, following Lady Ada Lovelace's dictum, that the machine "can do [only] whatever we know how to order it to perform" (Lovelace 722), or in the anxious language of the mid $20^{\text {th }}$ Century, that it is but a 'fast moron'. ${ }^{12}$ In the 1950 s IBM made this phrase doctrine to salve public fears of artificial intelligence following the successes of the machine at the game of draughts and the ramping up of publicity for the new 'giant brain' (McCorduck 159). IBM's mantra then went viral. But such is not the machine they had or we have, the one von Neumann helped to design, nor the one for which he and Herman Goldstine sketched the basics of programming in their report, "Planning and coding of problems for an electronic computing instrument". They pointed out that the difference in design (which in effect transcends Lady Lovelace's dictum) is the provision allowing a running program, conditional on the outcome of previous operations, to deviate from the linear sequence of instructions or to rewrite those instructions on the fly. They explained - note these words well - that coding "is not a static process of translation, but rather the technique of providing a dynamic background to control the automatic evolution of a meaning" as the machine follows unspecified routes in unspecified ways in order to accomplish specified tasks (Goldstine and von Neumann 2). Thus Herbert Simon: "This statement - that computers can only do what they are programmed to do is intuitively obvious, indubitably true, and supports none of the implications that are commonly drawn from it."13 The idea of 'machine' behind it is, as Marvin Minsky remarked, "precomputational" (McCorduck 71).

The high level of complications which result from this design, Goldstine and von Neumann went on to note, are "not hypothetical or exceptional... they are indeed the norm"; the power of the machine "is essentially due to them, i.e. to the extensive combinatorial possibilities which they indicate." (Goldstine and von Neumann 2) In essence, as von Neumann suggested four years later, machines "of the digital, all-or-nothing type" work by combining and recombining the data under given constraints until coherent patterns emerge (von Neumann 16). In a nutshell, then, the value-added at this stage is combinatorial.

\footnotetext{
${ }^{11}$ McCulloch and Pitts; McCulloch 12.

12 E.g. Soule 173-4; Andree 2, 106; "The Month in Science"; Rathburn 11; Gill 8; Chaplin 16.

13 Simon 67; see also Feigenbaum and Feldman 3-4.
} 
For an analogy take what happens in a research library, which provides a large number of modular resources in a standard format so that a variety of readers with unforeseen purposes may combine and recombine them ad lib. (This scheme goes back at least to the Library of Ashurbanipal, in the $7^{\text {th }}$ Century BCE, if I am not mistaken.) On a larger scale, in more recent form, we see more or less the same with the Web, on a smaller scale with a single codex, particularly obvious when it is designed as a reference work, such as a critical edition built to foster recombinatorial liberties. But my point is the familiarity, the humanity of this way of working, though now by the perhaps unfamiliar means of statistical tools for finding patterns in masses of data. Surprises from the process begin to emerge, Turing suggested by analogy to the critical mass of a nuclear reaction, at a quantitative threshold of complexity (Turing "Computing Machinery and Intelligence" 454). The successes of combinatorics in digital humanities are to be found, for example, in stylometric analysis as well as, for example, the many 'distant reading' projects of the Stanford Literary Lab.

\section{Construal}

Now for the third phase, at which that retranslation happens.

Modelling is of course iterative. It goes round and round, or more accurately, when it gets somewhere, it goes in a progressive spiral. I often depict the process as in Figure 7. But in such illustrations the modeller's reasoning is omitted, suggesting (which I think often to be the case) that the result from any state of the model is unproblematically compared to the modelled object and revisions made to the model. For our purposes, the value of Gooding's work with Faraday's laboratory notebooks - let's return to his diagram (Figure 5) - is its illumination of that overlooked point at which the modeller makes sense of results from the modelling apparatus. In other words, Gooding shifts our attention from those results to the modeller's making sense of them, to those "flexible, quasi-linguistic messengers between the perceptual and the conceptual" that go into the making of new knowledge (Gooding "How do scientists reach agreement" 208). We start paying attention to the interchange between digitally mediated and unmediated cognitive processing. The experimental scene moves inside.

I think Aden Evens is basically right when he argues, in his recent book, The Logic of the Digital, that this logic extends from the making of digital signals in circuitry and the extravagant engineering which maintains their crisp, discrete form; through the many layers of software; through the representations in the user-interface; to the uses the user makes of whatever digitised resources the interface provides. I argue 
that the polarising which the digital effects and the resonance between machine and enquirer that this polarisation enables comprise the intersection where a genuine digital humanities - a practice of as well as in the humane disciplines - takes place.

Abundant work in human-computer interaction and cognitive psychology thus comes into view. Also artificial intelligence, which we need to take more seriously, for as it progresses it projects into the external world that internal digital voice and so, to some degree, joins the conversation. The situation then becomes anthropological and performative, and so invites the arts back in. I will not spin this out further to suggest an ever-widening circle of disciplines, only ask you to look out for them, and to use their help in building an agenda for digital humanities that will fulfil the promise suggested in Figure 8.

\section{References}

"The Month in Science". Popular Science vol. 173, no. 4, 1958, pp. 11.

Andree, Richard V. Programming the IBM 650 Magnetic Drum Computer and DataProcessing Machine. New York: Henry Holt and Company, 1958.

Busa, R. "The Annals of Humanities Computing: The Index Thomisticus". Computers and the Humanities no. 14, 1980, pp. 83-90.

Busa, R., SJ. "Guest Editorial: Why can a computer do so little?" Bulletin of the Association for Literary and Linguistic Computing no. 4, 1976, pp. 1-4.

Chaplin, A. H. "Needs and Aims: The situation at the British Museum, the Bodleian Library, Oxford, and Cambridge University Library". The Brasenose Conference on the Automation of Libraries. Ed. John Harrison and Peter Laslett. 9-16. London: Mansell, 1967.

Due, Otto Steen. Changing Forms: Studies in the Metamorphoses of Ovid. Classica et Mediaevalia: Dissertationes X. Copenhagen: Gyldendal, 1974.

Evens, Aden. The Logic of the Digital. London: Bloomsbury, 2015.

Farbaky, Péter and Louis A. Waldman, eds. Italy and Hungary: Humanism and Art in the Early Renaissance. Acts of an International Conference, Florence, Villa I Tatti, 68 June, 2007. Florence: Leo S. Olschki, 2011.

Feigenbaum, Edward A. and Julian Feldman, eds. Computers and Thought. New York: McGraw-Hill, 1963.

Gill, William A. "Economic Considerations in the Use of Electronic Computers". Computers and Automation vol. 11, no. 8, 1962, pp. 6-12, 16. 
Goldstine, Herman H. and John von Neumann. Planning and Coding of Problems for an Electronic Computing Instrument: Report on the Mathematical and Logical aspects of an Electronic Computing instrument. Part II, Vol. 1-3. Princeton NJ: Institute for Advanced Study, 1947. https://library.ias.edu/files/pdfs/ecp/planningcodingof 0103inst.pdf. Accessed 3 December 2017.

Gooding, David. "How do scientists reach agreement about novel observations?" Studies in the History and Philosophy of Science vol. 17, no. 2, 1986, pp. 205-30.

Gooding, David. "Varying the Cognitive Span: Experimentation, Visualization, and Computation". In The Philosophy of Scientific Experimentation. Ed. Hans Radder. 255-300. Pittsburgh PA: University of Pittsburgh Press, 2003.

Kenny, Anthony. Computers and the humanities. The Ninth British Library Research Lecture. London: British Library, 1992.

Liu, Alan. "Where is Cultural Criticism in the Digital Humanities?" In Debates in the Digital Humanities. Ed. Matthew K. Gold. 492-509. Minneapolis MN: University of Minnesota Press, 2012.

Lovelace, Countess Ada. Translator's notes to L. F. Menabrea, "Sketch of the Analytical Engine invented by Charles Babbage, Esq." In Scientific Memoirs from the Transactions of Foreign Academies of Science and Learned Academies and from Foreign Journals. Ed. Richard Taylor. Vol. III. 666-731. London: Richard and John E. Taylor, 1843. https://archive.org/details/scientificmemoir03memo. Accessed 3 December 2017.

Mahoney, Michael Sean. Histories of Computing. Ed. Thomas Haigh. Cambridge MA: Harvard University Press, 2011.

McCarty, Willard. "Encoding persons and places in the Metamorphoses of Ovid: 1. Engineering the text". Texte: Revue de Critique et de Théorie Littéraire no. 13/14, 2003, pp. 121-72.

McCarty, Willard. "Encoding persons and places in the Metamorphoses of Ovid: 2. The metatextual translation". Texte: Revue de Critique et de Théorie Littéraire no. 15/16, 2004, pp. 261-305.

McCarty, Willard. Humanities Computing. Houndmills, Basingstoke: Palgrave Macmillan, 2014/2005.

McCorduck, Pamela. Machines Who Think: A Personal Inquiry into the History and Prospects of Artificial Intelligence. San Francisco CA: W. H. Freeman and Company, 1972.

McCulloch, Warren S. "What is a Number, that a Man May Know It, and a Man, that $\mathrm{He}$ May Know a Number?" The Ninth Alfred Korzybski Memorial Lecture. General Semantics Bulletin no. 26-27, 1961, pp. 7-18.

http://www.generalsemantics.org/misc/akml/akmls/26-27-mcculloch.pdf 
McCulloch, Warren S. and Walter H. Pitts. "A Logical Calculus of the Ideas Imminent in Nervous Activity". Bulletin of Mathematical Biophysics no. 5, 1943, pp. 115-33.

Milic, Louis. "The Next Step". Computers and the Humanities no. 1, 1966, pp. 3-6.

Moretti, Franco. "Conjectures on World Literature". New Left Review no. 1, 2000, pp. 54-68.

Olsen, Mark. "Signs, Symbols, and Discourses: A New Direction for Computer-Aided Literary Studies". Computers and the Humanities no. 27, 1993, pp. 309-14.

Olsen, Mark. "What can and cannot be done with electronic text in historical and literary research". Unpublished paper for the Modern Language Association annual meeting, San Francisco, CA, 1991.

Otis, Brooks. Ovid as an Epic Poet. Cambridge: Cambridge University Press, 1966.

Potter, Rosanne G. "Literary Criticism and Literary Computing: The Difficulties of a Synthesis". Computers and the Humanities no. 2, 1988, pp. 91-7.

Potter, Rosanne G. "Statistical Analysis of Literature: A Retrospective on Computers and the Humanities, 1966-1990". Computers and the Humanities no. 25, 1991, pp. 401-29.

Potter, Rosanne G. Literary Computing and Literary Criticism: Theoretical and Practical Essays on Theme and Rhetoric. Philadelphia PA: University of Pennsylvania Press, 1989.

Rathburn, Loyd. "Meetings". Southern California Chapter of the Special Libraries Assn. Bulletin vol. 22, no. 3, 1961, pp. 9-11.

Simon, Herbert A. The New Science of Management Decision. Rev. edn. New York: Harper \& Row, 1977/1960.

Smith, Brian Cantwell. "The Limits of Correctness". Computers and Society (ACM SIGCAS) no. $14-15,1985$, pp. 1-4, 18-26.

Soule, Gardner. "The Machine That Indexed The Bible". Popular Science 1956, 173-5, $242-$ 3.

Turing, A. M. "On computable numbers, with an application to the Entscheidungsproblem". Proceedings of the London Mathematical Society, ser. 2, no. 42, 1936, pp. 230-65.

Turing, A.M. "Computing Machiney and Intelligence". Mind vol. 49, no. 236, 1950, pp. 433-60.

von Neumann, John. "First Draft of a Report on the EDVAC". Contract No. W-67C-ORD4926, Between the United States Army Ordnance Department and the University of Pennsylvania. Philadelphia PE: Moore School of Electrical Engineering, 1945. https://archive.org/details/firstdraftofrepo00vonn. Accessed 3 December 2017.

von Neumann, John. "The General and Logical Theory of Automata". In Cerebral Mechanisms of Behavior. The Hixon Symposium. Ed. Lloyd A. Jeffress. 1-41. New York: John Wiley \& Sons, 1951. 


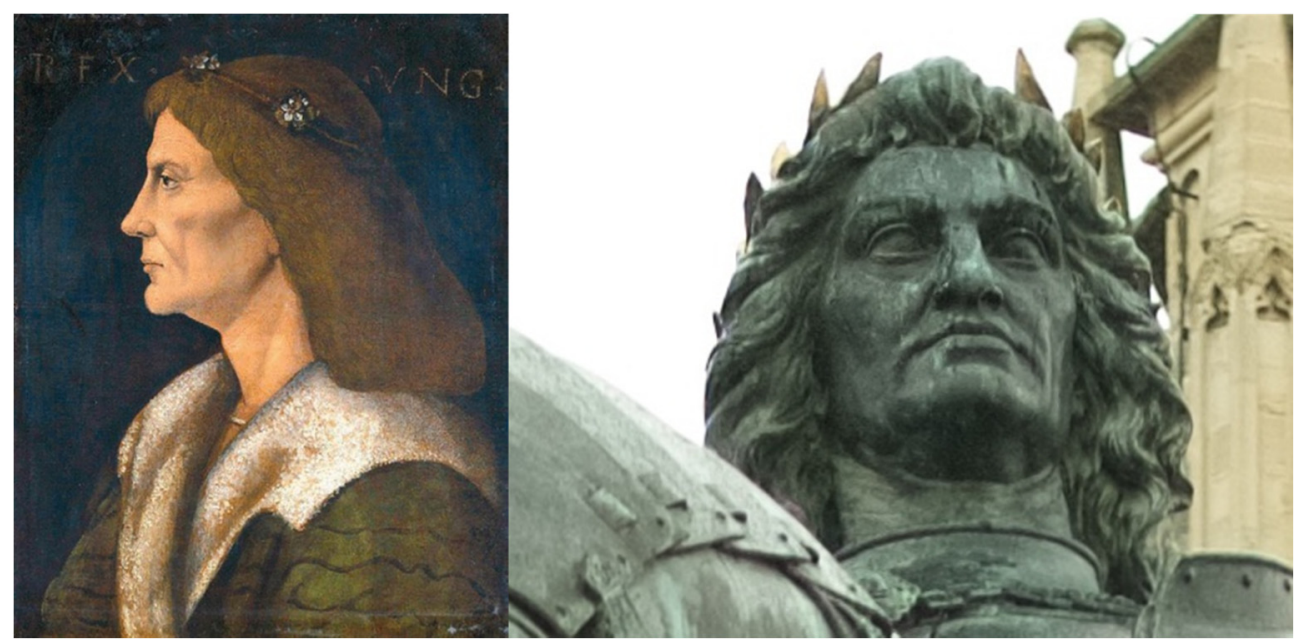

Figure 1. Matthias Corvinus (1443-1490) (Back to article)

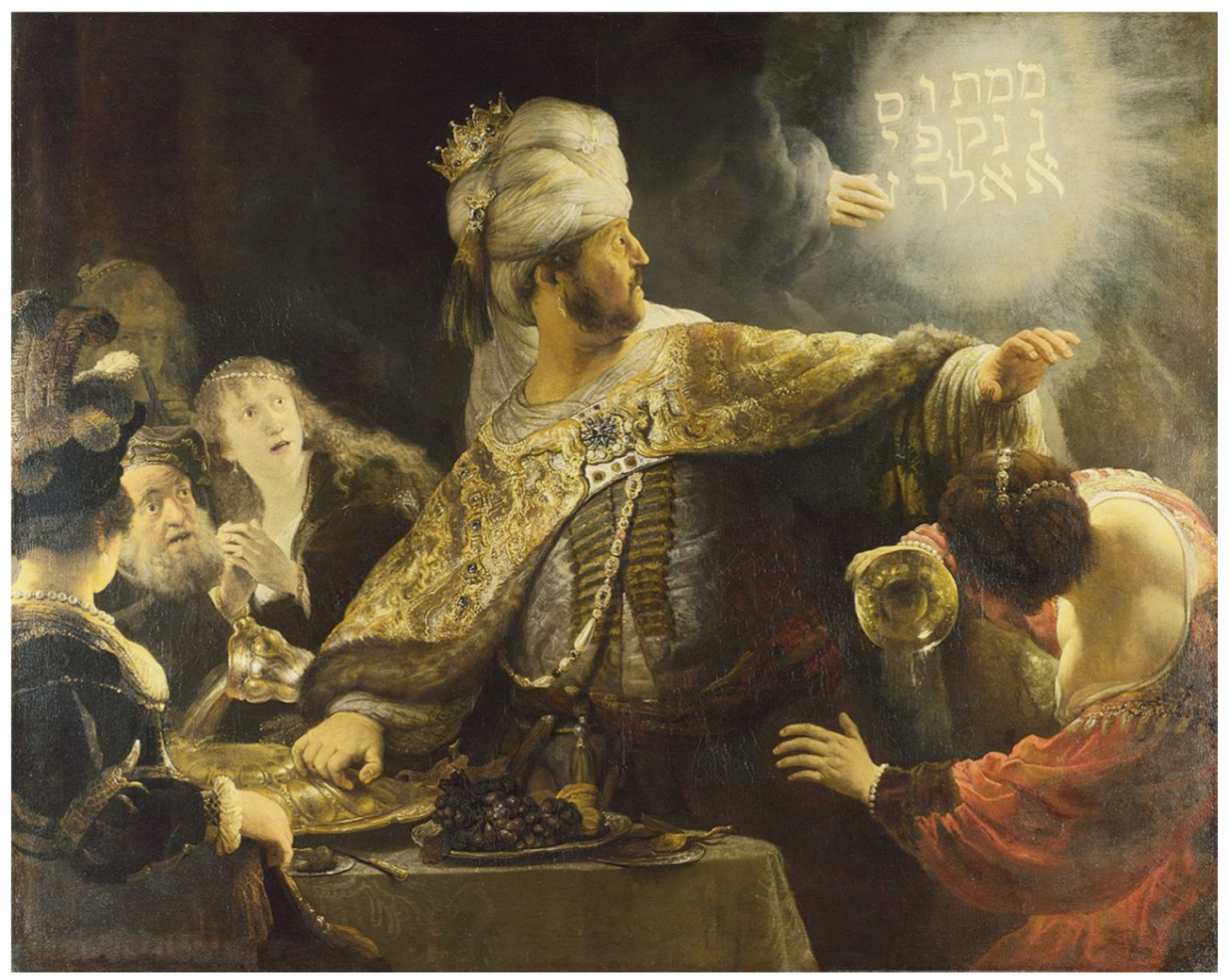

Figure 2. Rembrandt, Belshazzar's Feast (1635), from Daniel 5 (Back to article) 


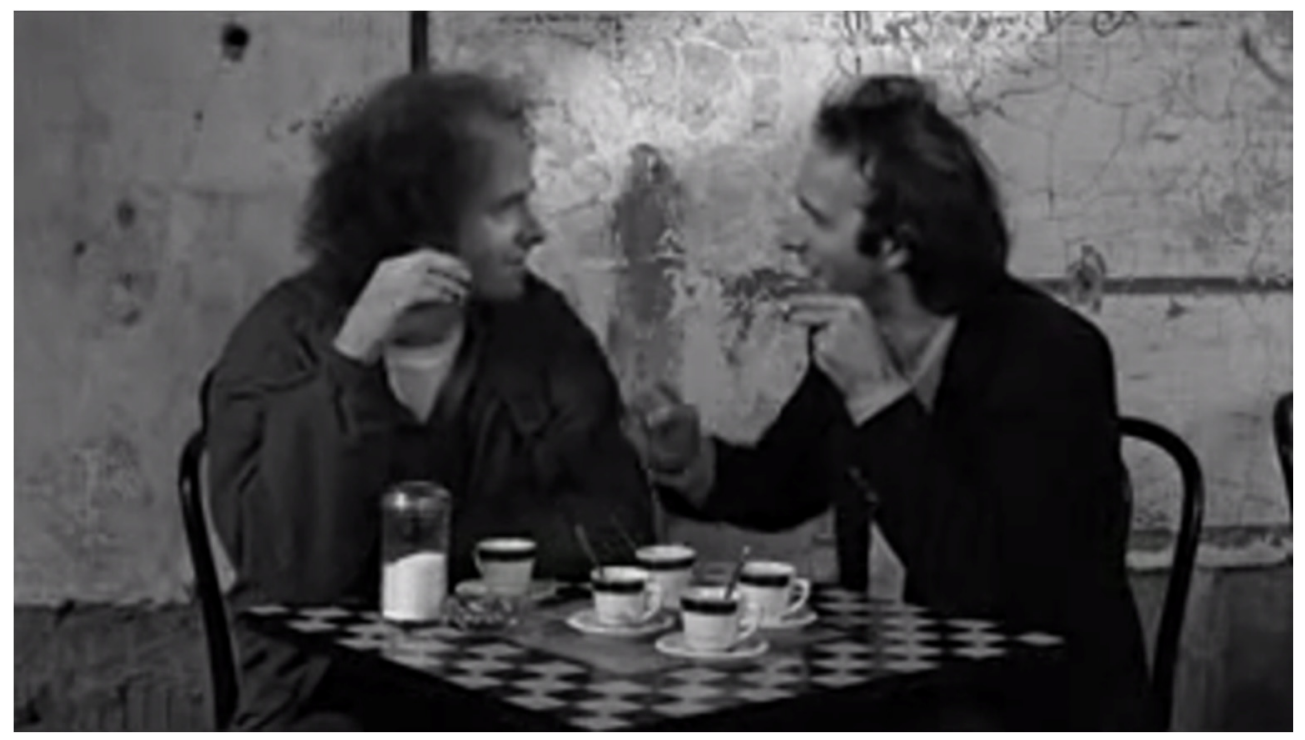

Figure 3. Jim Jarmusch, Coffee and Cigarettes (2003) (Back to article)

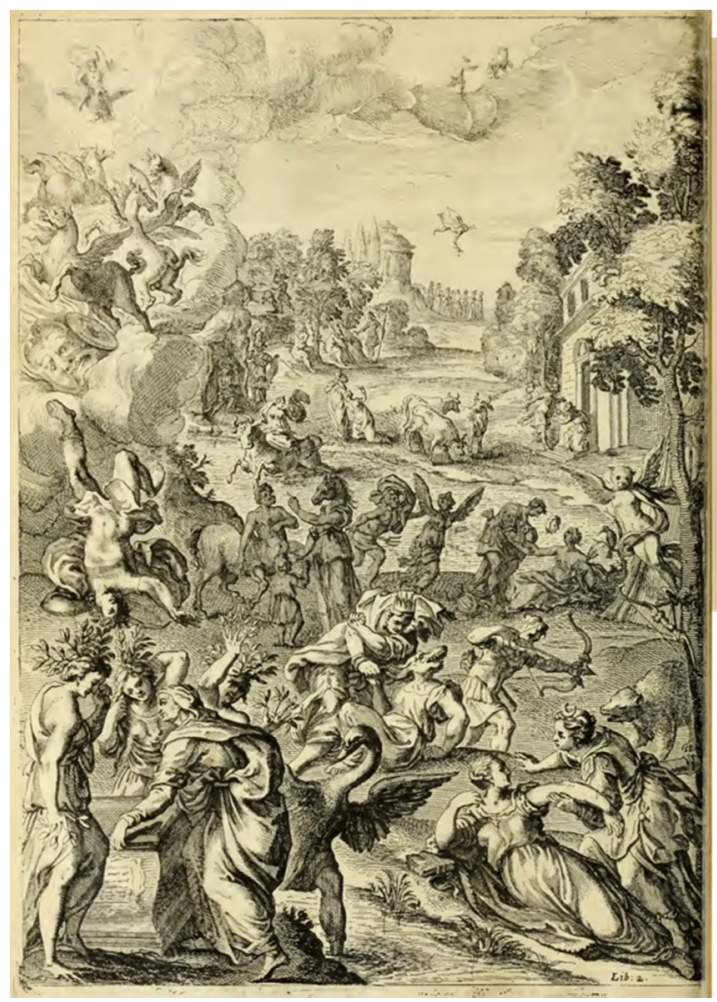

\section{O VID'S}

Metamorphosis. The Second Booke. Tн а Arovmant.

$\mathbf{R}_{\text {Af Phacton fires the World. His fiffers mourne }}^{\text {Af }}$ $\mathbf{R}_{\text {His Tragedie; who into Poplars turne; }}$ Ioue, Phoebe-like, Califto found a Man: Her, Iuno madea Beare. Shee, and her fon, Advanced ftarres, that fill the ocean fhun. Coronis, now a Crow, flyes . Neptunes frig ht. Nictimine is made the Bird of Night. The too-officious Raven, late Jo faire, Is plumid withblacke. Ocyroe groves a Mare. Phoebus, a Heardfman: Mercury, twice fuch; Phobus, a Heardaring Batrus into Tuch. Envious Aglauros, to a Statue, full of her minde's $\beta$ ots. Loue Iouc converts t'a Bull.

Figure 4. George Sandys, Ovid's Metamophosis Englished, Mythologiz'd and Represented in Figures (1632) (Back to article) 
The modeller

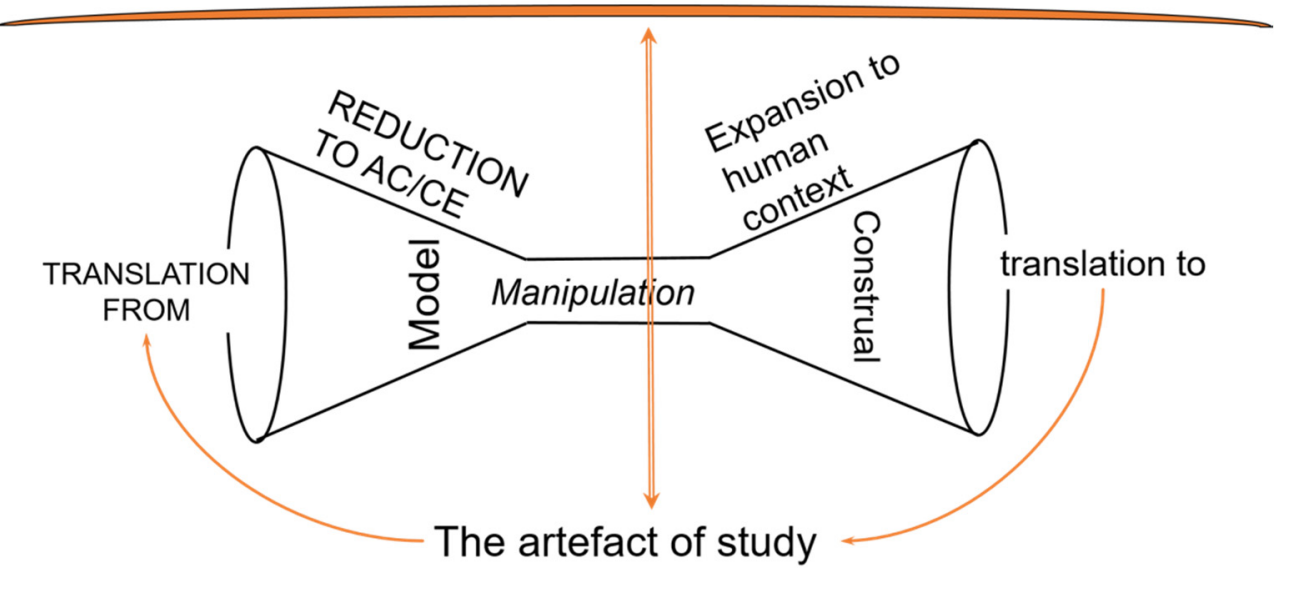

Figure 5. (Back to article - chapter 4) (Back to article - chapter 6)

We may compare a man in the process of computing a real number to a machine which is only capable of a finite number of conditions $q_{1}, q_{2}, \ldots, q_{1}$ : which will be called " $m$-configurations". The machine is supplied with a "tane" (the analnowe of nanerl runnino throuch it. and divided into

Alan Turing, "On computable numbers" (1936)

2.6. The throe specific parts $C A, C C$ together $C$ and $M$ correspond to the associative neurons in the hurian nervous system. It remains to discuss the equivalents of the sensory or afferent and the motor or efferont neurons. These are the input and the output organs of the deJohn von Neumann, "First report on the EDVAC" (1945)

Figure 6. (Back to article) 


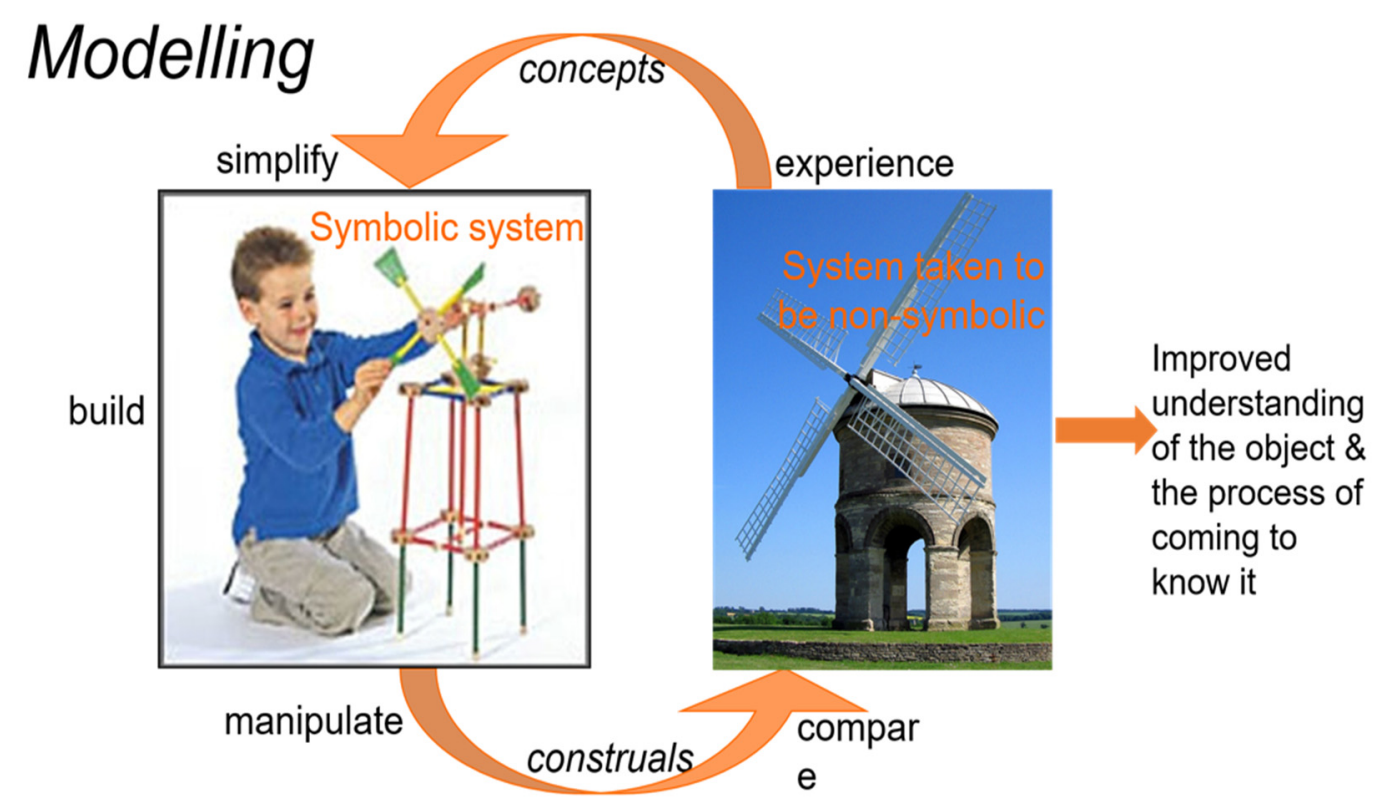

Figure 7. (Back to article)

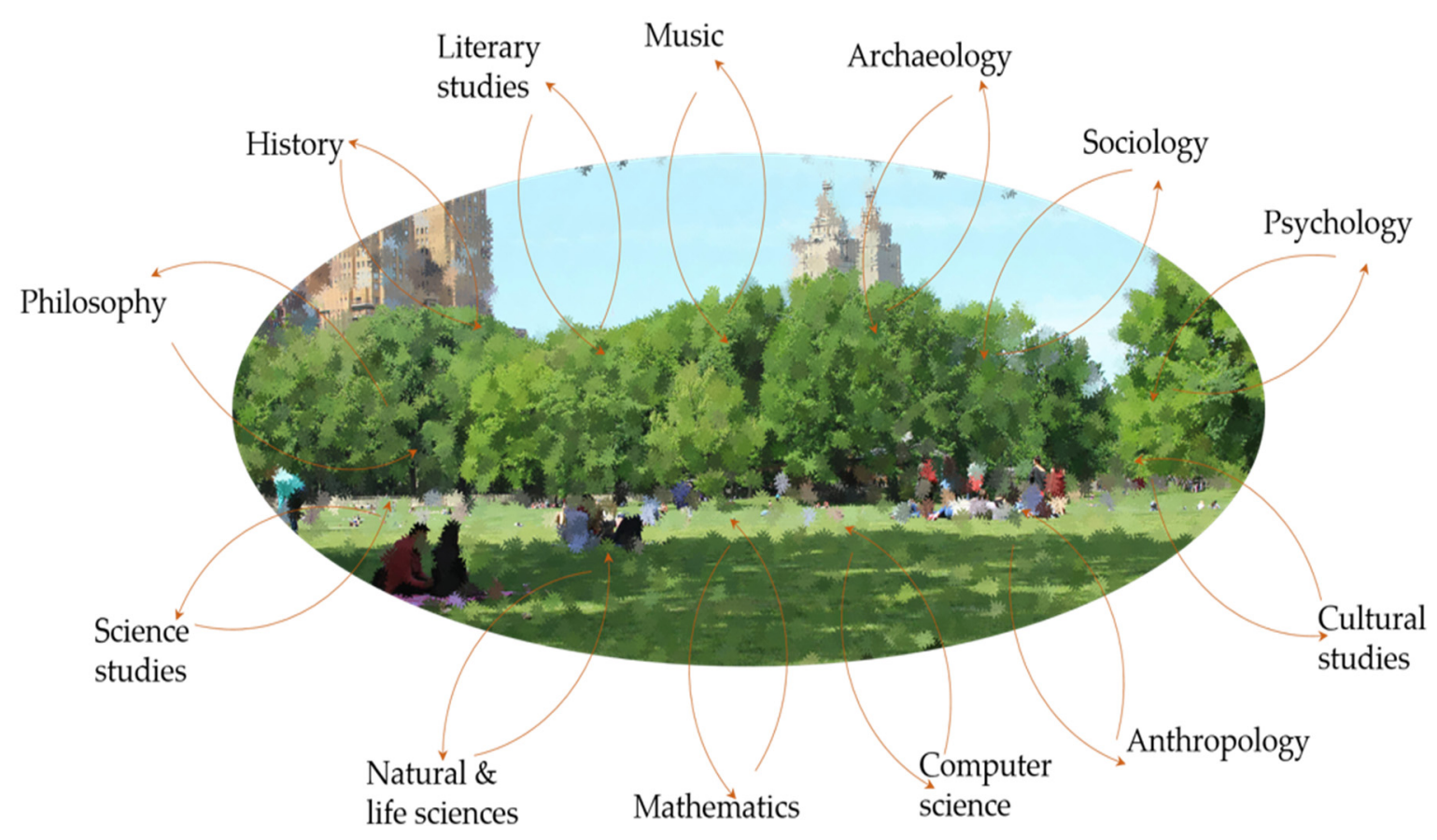

Figure 8. (Back to article) 